\title{
Impact of Monetary Policy on Stock Price: Evidence from Bangladesh
}

\author{
Afrin Rifat \\ Department of Accounting and Finance, School of Business and Economics, North South University, Dhaka, Bangladesh \\ Email address: \\ afrin.rifat@northsouth.edu \\ To cite this article: \\ Afrin Rifat. Impact of Monetary Policy on Stock Price: Evidence from Bangladesh. Journal of Investment and Management. \\ Vol. 4, No. 5, 2015, pp. 273-284. doi: 10.11648/j.jim.20150405.29
}

\begin{abstract}
This study intends to explore the impact of monetary policy on the performance of stock market from the perspective of a developing country-namely Bangladesh. The issue of monetary policy has been a subject of debate among several financial economists since a long time. Monetary policy is basically that part of the macroeconomics, which aims to achieve a set of objectives that are, conveyed in terms of several macroeconomic variables such as inflation, real output, money supply, exchange rate etc. As a result, any change in the monetary policy will have an effect on these variables. Understanding the sensitivity of stock market with respect to these variables of monetary policy frameworks is very important, particularly to recognize the monetary policy mechanism transmission into the stock market. This paper investigates whether current economic activities or more specifically the monetary policy tools of Bangladesh can explain stock market returns by using a number of econometric models of measuring long-run and short-run relationship between monetary policy tools and stock price.
\end{abstract}

Keywords: Bangladesh, Monetary Policy, Dhaka Stock Exchange (DSE), Stock Return

\section{Introduction}

In the field of economics and finance, the effect of monetary policy on the real asset market has been and proceeds to be one of the most popular studied topics. Monetary policy is used in mostly by the central banks as a tool to influence the economic variables such as GDP, Industrial Production Index, Consumer Price Index, Exchange Rate or the Inflation rate. One of the most popular monetary tools applied by central bank is to alter the short term interest rate to achieve the macroeconomic goals of government. On the other hand, in modern economy; stock exchange plays a very important role. For example stock exchange can help an economy to diversify the domestic funds and channels into productive investment. Nevertheless for a stock exchange of any country, to play such role, the existence of a significant relationship between macroeconomic variables and stock market is very essential. Moreover, we all know that, modern economy is a market based economy where the capital market plays a very significant role. It is the capital market which transfers the excess money of the savers to the borrowers which is at the key of the developments of an economy. In a country economic growth and propensity cannot happen, as long as their capital market is inefficient. As a result we can say that economic growth and prosperity is possible only when capital market works efficiently [1].

According to Efficient Market Hypothesis (EMH), investors should know, all the necessary or relevant information regarding their investment and also about profit maximizing and the macroeconomics variables which might lead to a supernatural earning. This clearly indicates that stock price actually reflects the shocks from macroeconomic variable. In case of the existence of EMH in capital market, markets become efficient. Therefore we can say that stock market plays the vital role to transfer of funds from capital borrowers to capital investors which is very essential for economic growth. Therefore, in order to understand how monetary policy changes transmit to the economy and how the market responds to the changes is important for both policy makers and investors.

Poole et al. [2] tested and showed how the monetary policy changes affected the bank bill rate in different maturities using U.S. data from 1988 to 1999. According to their study, market is becoming better day by day in forecasting the monetary policy action. The research conducted by Cook and Hahn [3] was one of the first, which 
found a significant relationship between monetary policy and bond return by using the event study method to test the daily effect of monetary policy on asset prices. In 2001 another researcher, Kutter has further extended the study of Cook and Hahn by decomposing the interest rate changes into expected and unexpected changes and found a significant reaction on the part of stock market to surprise monetary policy changes [4]. Afterwards, Bredin et al. [5] and Gregoriou et al. [6] employed the method of Kutter to explore the effect of monetary policy on stock returns and found the similar kind of significant relationship.

\section{Literature Review}

Monetary policy in any country, attempts to achieve a set of objectives that are expressed in terms of macroeconomic variables such as inflation, real output, employment, money supply, exchange rate etc. Nevertheless, monetary policy actions such as changes in the central bank discount rate can have an indirect effect on these variables and considerable lags can be involved in the policy transmission mechanism [7]. For equity prices, an approach for determining stock prices is commonly assumed to be forward looking. For monetary policy, the monetary authority affects both the current and the expected future real interest rate. This in turn has an effect on decisions of household to consume and to invest, respectively, in terms of timing. To establish the relationship, changes in expected future interest rate serving as a discount rate are directly attributed to the link between monetary policy and the stock market. Preceding empirical evidences also strengthen the notion that monetary policy (restrictive or expansive) affects both contemporaneous and future stock returns. It is generally believed that restrictive monetary policy and expansionary monetary policy lead to lower stock prices and higher stock prices respectively. Moreover, according to some researchers, changes in monetary policy influence forecasts of market determined interest rates, equity cost of capital, and expectations of corporate profitability [8]. The basic idea is that an increase in interest rates due to a restrictive monetary policy will force investors to raise funds through the equity market. Besides in order to heighten the demand for stock, the price will drop to a level that will attract investors, in the short run at least. According to Bernanke and Gertler [9], apart from the interest rate, monetary policy affects the external finance premium as well, which brings the concept of credit channel of monetary transmission mechanism to focus. However, the primary focus has always been on banks as they are considered as the major conveyors of monetary policy shocks to the real sectors of the economy.

The relationship between monetary policy and stock market has been a topic for study in several parts of the world since long. In 2007, Mbutor [10] studied the lending channel of Monetary Policy Transmission in Nigeria. He has used GDP as a dependent variable on the explanatory variables which includes consumer price index as a proxy for domestic prices, treasury bill rates as a proxy for minimum rediscount rate, broad money (M2), exchange rate, total quantity of loans and maximum lending rate as a proxy for the price of loans. According to this study, increase in the minimum rediscount rate by 0.25 percentage points will leave the quantity of loans made by the banks unaffected in the first period [10]. This finding of Mbutor is consistent with the concept that loan contracts need some time to be adjusted. Nonetheless this study proves that an increase in the minimum rediscount rate (MRR) forces banks to cut down the amount of loans that they extend to their customers. Another important source of monetary policy transmission mechanism is exchange rate [11]. According to Kim [12], exchange rate is one of the major determinants of business profitability and equity prices.

Mukherjee et. al tested the relationship between stock prices and several macroeconomic variables-exchange rate, money supply, index of industrial production, inflation and interest rates- in 1995 and observed a positive relationship for all other variables except for inflation and interest rates where a miscellaneous relationship was experimented [13]. Similar to the study of Mukherjee et. al., Ibrahim has conducted a study in 2003 and tested the long run relationship and dynamic interactions between Malaysian Stock Market and various economic variables [14]. He has used real output, aggregate price level, money supply, and exchange rate as explanatory variables for the variations in stock price movements [14]. The evidences from this study showed a positive relationship between the Malaysian stock price index and economic variables such as money supply, consumer price index \& industrial production. However, the study found a negative relationship between that stock price index and exchange rates.

Another study has been conducted by using the Vector Autoregressive (VAR) model to test the relationship between stock prices and macroeconomic factors (exchange rate, industrial production, money supply, and consumer prices) in Cyprus by Tsoukalas [15]. The evidences from the study showed a strong relationship between stock prices and all the macroeconomic factors.

Thorbecke [16] on the other hand used a number of alternative methodologies to study the relationship between monetary policy and stock prices in the United States. One of the methodologies that he has employed in his research is VAR model and has used macroeconomic factors such equity returns, output growth, inflation, and the federal funds rate. In his study he has found that monetary policy shocks, measured by orthogonalized innovations in the federal funds rate, have a greater impact on smaller capitalisation stocks [7], which is in line with the hypothesis that monetary policy affects firms' access to credit [9]. Another methodology that Thorbecke [16] employed in the same study is the Boschen and Mills' [17] index which he has used as an alternative measure of monetary policy conditions. The results from this methodology once again confirmed the result he got from VAR model that expansionary monetary policy exerts a large and statistically significant positive effect on monthly stock returns. Patelis [18] also examined whether shifts in the 
monetary policy stance is responsible for at least some portion of the observed predictability in excess stock returns in the United Ststes. He has used the long-horizon regression methodology in his study, using two sets of explanatory variables-monetary policy variables and financial variables. According to his study, monetary policy variables are significant predictors of future returns, although they cannot account fully for the observed stock return predictability [7].

In 2006, Cassola and Morana [19] employed a cointegrated VAR model including real GDP, inflation, real M3 balances, short term interest rate, bond yield, and real stock prices with an intention to inspect the transmission mechanism of monetary policy in the Euro area. Through their study they have found out that a permanent positive monetary shock has a temporary positive effect on real stock prices. The results of Cassola and Morana [19] support the findings of Jensen and Johnson [20] that monetary policy developments are indeed associated with stock returns. In their study Jensen and Johnson showed that long-term stock returns following discount rate decreases are higher and less volatile than returns following rate increases [7]. They have used discount rate as a proxy for the state monetary policy in their study because discount rate is typically regarded as a signal of monetary and possibly economic developments. According to several financial economists there are various reasons behind the effects of changes in the discount rate on stock returns. For instance, discrete policy rate changes influence forecasts of market determined interest rates and the equity cost of capital [7]. In addition, Waud [8] stated in his study that changes in the discount rate possibly affect expectations of corporate profitability. In a following study, Jensen et al. [21] extended the Fama and French [22] analysis by signifying that the monetary policy affects investors' required returns. In their study Jensen et al. [22] found that "predictable variation in stock returns depends on monetary as well as business conditions, with expected stock returns being higher in tight money periods than in easy money periods" [7].

One of the most important monetary dynamics is inflation which reflects money growth per unit of output. The poor performance of the stock market during periods of inflation is a well studied topic in financial literature [23]. In 1988, United States Presidential Task Force has conducted a study on market mechanisms for the Group of Seven Countries and found a significant negative relationship between real stock returns and inflation on four of the seven countries. 'Inflation fears' was cited as a probable contributing reason behind the stock market crash of October 1987 which led to the setting up of the task force [24]. Previously this negative relationship between stock returns and both actual and expected inflation was recognized by the studies of Nelson [25] and Fama and Schwert [26]. There were basically two lines of thoughts that have been come forward as possible explanations for this anomaly particularly for the United States stock market [27]. The first line of thought focused on 'tax effect' hypothesis which deals with "the treatment of depreciation and the valuation of inventories in periods of inflation, particularly that share prices fail to keep pace with inflation because inflation increases corporate tax liabilities and thus reduces after tax earnings" [28]. In this regard inflation can be considered as a reason behind the changes in stock prices. The second line of thought focused on the 'proxy-effect' hypothesis which is the alternative explanation of the reason behind the inverse relationship the between real stock returns and inflation. Two main assumptions are involved in this case -"one that cyclical variations in earnings and output growth are positively correlated, and the other that monetary policy is counter cyclical" [28].

According to Eugene Fama [29] the forward looking nature of individuals' money demand causes an inverse relationship between existing inflation and expected future growth in national productivity. In consequence a decrease in future output growth leads to a decline in current stock returns along with an increase in existing inflation. In a subsequent study [30] supported Fama by providing evidences against any direct relationship between stock returns and inflation. However unlike Fama, in their study Benderly and Zwick argued that the relationship runs from inflation to expected output growth [28]. On the other hand, in 1983, Geske and Roll [31] extended Fama's argument and stated that a "reverse causality" actually drives the inverse relationship between stock returns and inflation. According to their study, when deficit begins to grow as a result of a decrease in output, outstanding government debt increases. As a response to this movement when central bank decides to monetize a portion of this debt, inflation occurs. However there always exists a group of rationale individuals who are capable of anticipating such debt monetization. As a result a decline in the stock market will ultimately lead to an increase in expected future inflation [29]. Thus, according to Geske and Roll [31], stock returns are inversely correlated with expected future inflation. Later another study by Kaul [32], regarding the relationship between stock return and inflation produced the similar results. Nevertheless in contrast to Geske and Roll, this study did not pivoted on debt monetization entirely.

On the other hand, a study has been carried out to examine the relationship between inflation, output and stock prices in the Chinese economy by Zhao in 1999 [33]. Evidences from this study showed a significant but negative relationship between stock prices and inflation and a similar kind of relationship between output and stock prices. In 2001, Udegbunam and Eriki [34] conducted a similar kind of study on the Nigerian Stock Market, and observed strong evidence which strengthen the earlier proposition that inflation indeed wields a significant negative effect on stock prices. Moreover, in their study Udegbunam and Eriki provided evidences in favour of a strong relationship between stock prices and Gross Domestic Product (GDP), interest rate, money stock and financial deregulation. However unlike the preceding studies mentioned, a recent study by Omotor [23], provided evidences in favor of a significant and positive relationship between inflation and stock prices in Nigerian Stock Market.

In 2007, Ahmed et. al. [35] examined the relationship 
between monetary policy and stock price in Bangladesh using the VAR model including consumer price index, industrial production index, 28-day treasury bill rate, money supply (M1) and all share price index of Dhaka Stock Exchange (DSE) as economic variables. According to this study, contractionary monetary policy shock has insignificant negative effect on the stock price index. On the other hand, Banerjee and Adhikary [36] tested the effects of interest rate and exchange rate (USD against BDT) changes on share price in the stock market of Bangladesh in 2009 by using Johansen-Juselius procedure and the Vector Error Correction Model (VECM) respectively and found that the interest rate and exchange rate changes affect for the stock market in the long-run and there is no significant influence in the short-run [37].

Rahman and Uddin [38] explored the relationship between stock prices and exchange rates by using Johansen cointegration and Granger causality test in three emerging South Asian countries - Bangladesh, India and Pakistan and found neither cointegrating relationship nor any causal relationship between stock prices and exchange rates in the countries. However, Alam \& Uddin [39] studied the linear relationship between share price and monetary policy, particularly between share price and changes in interest rate on DSE. Evidences from his study showed that monetary policy has significant negative relationship with share price.

Another researcher, Quadir examined the relationship of macroeconomic variables-treasury bill interest rate and industrial production with stock returns in DSE by using Autoregressive Integrated Moving Average (ARIMA) model and observed a positive relationship between Treasury bill interest rate and industrial production with market stock returns [40]. A further research has been conducted on the relationship between monetary policy and stock price in DSE by Saidjada et. al. in 2013 [37]. Johansen cointegration approach and VEC model have been used in this study to unveil the relationship between stock price and broad money, reserve money \& 91-day treasury bill rate. The study found a negative relationship between stock price and treasury bill rate but could not pin point any significant relationship between stock price and broad money $\&$ reserve money.

\section{Data Description and Research Method}

The monthly data employed in this article range from January, 2003 through December, 2013. Monthly data have been used because it avoids the problems of thin trading and price limits in a stock market [41]. As stock market data, the DSE all share price indices were collected. The discount rate of Bangladesh Bank has been used as a proxy for monetary policy. Consumer price Index has been used as a proxy for Inflation because inflation can directly affect stock prices and monetary policy. Therefore, in order to effectively examine the influence of monetary policy on stock returns, it is imperative to put the impact of inflation on stock returns under control. The conditioning variables for Bangladesh Bank feedback rule include the contemporaneous values of money supply and exchange rate, as well as the lagged values. As a result broad money of both Bangladesh and exchange rate of Bangladeshi Taka against U.S Dollar has been used along with central bank's discount rate.

The relationship between stock prices and monetary policy has been tested through several methods by many researchers in the past. In this research article one of the most popular methods to examine the effectiveness of monetary policy on stock price-the Vector Autoregressive (VAR) model have been used. This model has been used mainly for three reasons-there is no exogenous variable because all are considered as endogenous which can give us a better result. Furthermore, VARs allow the value of a variable to depend on more than just its own lags or combinations of white noise terms, so VARs are more flexible other than univariate models. In addition, the forecasts generated by VARs are often better than 'traditional structural' models. Now-a-days VARs are more commonly used method to measure the relationship between monetary policy instruments and stock price. Geske and Roll [31] and Kaul [32] individually studied the fundamental relationship between monetary policy and stock market returns using VARs. Recently many researchers have been used VARs approach to estimate such relationship, for instance, Thorbecke [16] and Neri [42]. The main reason behind the wide use of VARs by researchers to examine monetary policy transmission is because of their ability to recognize the effects of the policy without a complete structural model of the economy.

The motive of this research paper is to inspect that whether there will be any long-run cointegrating relationships between the stock market and monetary policy instruments. The base estimating equation to examine the relationship in log-linear form is as follows:

$$
\operatorname{lnSPIt}=\alpha+\beta \operatorname{lnDRt}+\gamma \operatorname{lnCPIt}+\psi \operatorname{lnMSt}+\Omega \operatorname{lnERt}+\varepsilon \mathrm{t}
$$

Where, SPI = stock market indices of Bangladesh, DR = Discount Rate, MS=Money Supply, $\mathrm{CPI}=$ Consumer Price Index and $\mathrm{ER}=$ exchange rate.

There are two reasons behind the conversion of the variables into natural logs. Firstly, if variables are converted into natural $\operatorname{logs}$ then coefficients of the cointegrating vector can be interpreted as long-term elasticities if the variables are in logs. On the other hand the second advantage is, if the variables are in logs, the first difference can be interpreted as growth rates. The error $(\varepsilon)$ term is assumed to be iid (independently and identically distributed). On the other hand, the additional symbol $\mathrm{t}$ has been used for the time subscript.

To implement the empirical design, the nature of the data distribution has been studied by using a series of tests- Unit Roots, Cointegration, Vector Error Correction models (VECM) etc. However, the empirical tests have been started by using a simple descriptive analysis. The standard descriptive statistics test includes the results of- mean, median, standard deviation, skewness and kurtosis. The 
normality of data distribution has also been estimated by studying the Jarque-Bera test given by the descriptive statistic test.

After the analysis of descriptive statistics, this paper approaches the most important part of the its empirical studies where the following series of tests has been ran.

\section{Unit Root Test}

According to many studies, most macroeconomic time series are non-stationary with a deterministic trend [43]. There are several reasons behind the importance of the concept of non-stationarity and the essentiality of those variables non-stationary being treated differently from those that are stationary. The stationarity or non-stationarity of series can strongly influence its behavior and properties [44]. In addition, the use of non-stationary data can results in spurious regression. If one stationary series regressed on another, the t-ratio on the slope coefficient usually become insignificantly different from zero, while the value of $R^{2}$ is generally expected to be quite low. This symptom essentially indicates that the variables are not related to one another. However, even two unrelated variables would have high $\mathrm{R}^{2}$, while trending over time. As a result, running regression with such data produces questionable, invalid and spurious outcomes. In order to eliminate such problem, a stationarity test must be performed for each variable. That is the reason behind performing an unit root test. In statistics, a unit root test examines the nonstationarity of a time series variable by using an autoregressive model. There have been a variety of proposed methods for conducting stationarity tests which include Dickey and Fuller (ADF) test, Phillips and Perron (PP) test, Kwaitkowski (KPSS) test. In this paper all three of these tests have been performed.

\section{Augmented Dickey-Fuller Unit Root Tests}

The most popular tests for unit root are the ones derived by Dickey and Fuller. According to the simplest DickeyFuller tests, the disturbances in a model are white noise, whereas ADF test is an extension which will allow for some serial correlation. The augment of Said and Dickey [45] regarding the basic autoregressive unit root test to accommodate general $\operatorname{ARMA}(p, q)$ models with unknown orders is referred to as the augmented Dickey- Fuller (ADF) test. The ADF test tests the null hypothesis that a time series has a unit root against the alternative while assuming that the dynamics in the data have an ARMA structure. In general he ADF test in the context of model can be specified as follows,

$$
\mathrm{z}_{\mathrm{t}}=\mu+\beta_{\mathrm{t}}+\varphi \mathrm{y}_{\mathrm{t}-1}+\varphi \Delta \mathrm{Z}_{\mathrm{t}-1}+\ldots .+\varphi \Delta \mathrm{y}_{\mathrm{p}-1}+\varepsilon_{\mathrm{t}}
$$

Where, $\mathrm{z}$ indicates all the explanatory variables along with the dependent variable.

Philips Perron Test

After ADF test, the most popular test for unit roots is Phillips Perron test which was developed by Philips \& Perron [46]. Phillips \& Perron have developed a more comprehensive theory of unit root non-stationarity [44]. Although, this test is similar to ADF test, but it incorporate an automatic correction to the DF procedure whereby allowing for autocorrelated residuals. Generally PP tests give the same conclusion as the ADF test and also face same kind of limitations.

\section{The KPSS Test}

"Kwitkowski et.al [47] (KPSS) have formulate an alternative to the DF test for stationary of a time series". The methodology of this alternative option is a test of nonstationarity against the null hypothesis of stationary in the model. In general the regression model has the following form,

$$
Z_{t}=\mu+\beta_{t}+\varphi \sum_{\substack{i=1 \\ i=1}}^{k} \eta i+\epsilon t, t=1,, T
$$

With stationary $\eta_{\mathrm{i}}$ and i.i.d. $\varepsilon_{\mathrm{t}}$ with an expected value of 0 and variance 1 . Here, $\mathrm{z}$ indicates all the explanatory variables along with the dependent variable.

\section{Johansen Cointegration Method}

There are two ways of testing the cointegrating relationship among variables or testing the possibility of a long-run equilibrium relationship in case of the nonstationarity of each variable - the Engle-Granger method or the Johansen-Juselius procedure- that can be used to overcome the related problem of spurious correlation and misleading inferences [36]. Cointegration analysis plays a very important part in the estimation of the error correction models (ECM). According to Engle and Granger [48], "when two variables are cointegrated, an error correction data generating mechanism exists, and vice versa." Additionally when two variables will be cointegrated, there there will be a very low chance of them drifting apart on an average [49]. This model as a result gives us an insight into the long-run relationship between the two variables while testing for the cointegration between two them. In this study, Johansen's Maximum Likelihood procedure for Cointegration has been applied to estimate the cointegration among the variables. Johansen's methodology has its beginning point in the vector autoregression (VAR) of order p generally given by,

$$
\mathrm{Y}_{\mathrm{t}}=\mathrm{A}_{1} \mathrm{Y}_{\mathrm{t}-1}+\mathrm{A}_{2} \mathrm{Y}_{\mathrm{t}-2}+\ldots \ldots \ldots . . . \mathrm{A}_{\mathrm{p}} \mathrm{Y}_{\mathrm{t}-\mathrm{p}}+\mathrm{BX} \mathrm{X}_{\mathrm{t}}+\varepsilon_{\mathrm{t}}
$$

Where $Y_{t}$ is a k-vector of variables which are integrated for 1 or also known as $\mathrm{I}(1), \mathrm{X}_{\mathrm{t}}$ is a d vector of deterministic variables, and $\varepsilon t$ is a vector of innovations. We can rewrite the model as:

$$
\Delta y_{t=} \Pi Z_{t-1}+\sum_{i=1}^{p-1} \Gamma i \Delta Y_{t-1}+B X_{t}+\varepsilon_{t}
$$

Where, $\Pi=\sum_{i=1}^{p} A_{i}-I$ and $\Gamma \mathrm{i}=-\sum_{j=i+1}^{p} A_{j}$

Here $\mathrm{Yt}$ is represent as a vector of nonstationary variables. The Johansen test focuses on an examination of the $\Pi$ matrix which can be interpreted as a long-run coefficient matrix, as in equilibrium, all the $\mathrm{Y}_{\mathrm{t}-\mathrm{i}}$ will be zero, while setting the error terms, $\varepsilon_{t}$ to their expected value of zero will leave $Y_{t-i}=0$. The information regarding the coefficient matrix between the levels of the series ( $\Pi)$ is decomposed as $\Pi=\alpha \beta^{\prime}$.On the other hand, the relevant elements of the $\alpha$ matrix are known as adjustment coefficients, whereas the $\beta$ matrix contains the cointegrating vectors. According to Johansen and Juselius, [50] "there are two likelihood ratio test statistics to test for 
the number of cointegrating vector". For instance, the first likelihood ratio statistics for the null of $r$ cointegrating vectors against the alternative of $r+1$ vectors is the maximum eigenvalue statistic whereas, the second statistic for the hypothesis of at most $r$ cointegrating vectors against the alternative is the trace statistic. Critical values for both test statistics can be found in Johansen and Juselius [50]. The number of lags which is a very important part of this cointegration test can be generally determined based on the information provided by the multivariate generalization of the AIC.

\section{Vector Error Correction (VEC) Model}

After performing the Johansen cointegration test, a Vector Error Correction model (VECM) has been estimated on the evidence of cointegrating relationship, for long-run causality and short-term dynamics. A VECM can be taken as a scaled down VAR model which allow us to identify the structural coefficients. Hence we can define a vector error correction (VEC) model as a restricted VAR which involves cointegration restrictions built into the specification. These types of models are designed in a way which allows the use of cointegrated non-stationary series. The VEC specification restricts the long-run behavior of the endogenous variables to converge to their cointegrating relationships while allowing a wide range of short-run dynamics [43]. In a VECM, the cointegration term has been seen as the error correction term as here a series of partial short-run adjustments have been used to correct deviation from long-run equilibrium. The VEC model used in this research paper can be specified as follows,

$$
\begin{aligned}
& \Delta \ln S P I_{t}=\alpha+\lambda e_{t-1}+\sum_{i=0}^{n} b_{i} \Delta S P I t-i+\sum_{i=0}^{m} c_{i} \Delta D R_{t-i}+ \\
& \sum_{i=0}^{k} d_{i} \Delta M S_{t-i}+\sum_{i=0}^{j} e i \Delta I N F_{t-i}+\sum_{i=0}^{1} f i \Delta E R_{t-i}+U_{t}
\end{aligned}
$$

The VECM approach is generally justified under the arguments that the identification and testing for the significance of the structural coefficients which underlies the theoretical relationship is essential. Since the simple VAR models do not allow the identification of structural coefficients nor do value the relevance of unit root tests, VECM model came into picture.

\section{Vector Autoregressive (VAR) Model}

Next in the absence of the cointegrating relationship among the variables, the vector autoregressive (VAR) model has been estimated. The Vector autoregressive models (VARs) based on Gaussian (normally distributrd errors) has frequent been popular choice as a description of macro-economic time series due to its good fit to such type of data [51]. VARs were popularised in econometrics as a generalised form of univariate autoregressive models by Sims [52]. A VAR is known as a systems regression model that can be considered a kind of hybrid between the univariate time series models and the simultaneous equations models. According to Angel and Fildes, "VAR approach is beneficial to use as it collects many causal variables" [53]. The VAR model can used in this research paper can be specified as follows,

$$
\begin{gathered}
\Delta \operatorname{lnSP} T_{t}=\alpha+\sum_{i=1}^{n} b_{i} \Delta S P I_{t-1}+\sum_{I=0}^{M} C_{i} \Delta D R_{t-i}+ \\
\sum_{i=0}^{k} d_{i} \Delta M S_{t-i}+\sum_{i=0}^{j} e i \Delta C P I_{t-i}+\sum_{i=0}^{1} f i \Delta E R_{t-i}+U_{t}
\end{gathered}
$$

The components of the vector $\mathrm{DR}_{\mathrm{t}-\mathrm{i}}, \mathrm{MS}_{\mathrm{t}-\mathrm{i}}, \mathrm{CPI}_{\mathrm{t}-\mathrm{i}}$ and $\mathrm{ER}_{\mathrm{t}-\mathrm{i}}$ are known as exogenous variables since their values are determined outside of the VAR system. The lag length for this model is determined by using multiple information criteria, particularly the AIC criteria.

In this research article, the relationship between stock price index and the other important monetary policy instruments has been tested through a series of tests. I have used both VAR and VECM approach to measure the effectiveness of monetary policy instruments on stock price index. Since, simple VARs do not identify structural coefficients and ignore relevance of unit root tests, VECM model has been estimated here.

\section{Empirical Studies}

This section includes detailed discussion of all the empirical results and their interpretations. For the purpose of simplicity, all the empirical results presented here, has been shown up-to two decimal points.

Summary Statistics
All the tables under this category represent the summary statistics of the variables under study. At 1st I did it on the level by taking the Ln of the raw data. After that the test was performed on the return series by taking the 1 st difference of the Ln series.

Table 1. Descriptive Statistics Test: Bangladesh (Level).

\begin{tabular}{llllll}
\hline & LSPI & LDR & LER & LMS & LCPI \\
\hline Mean & 7.18 & 1.71 & 4.13 & 7.27 & 4.59 \\
Median & 7.27 & 1.61 & 4.10 & 7.25 & 4.57 \\
Maximum & 8.39 & 1.95 & 4.27 & 8.10 & 4.95 \\
Minimum & 6.18 & 1.61 & 3.93 & 6.57 & 4.33 \\
Std. Dev. & 0.58 & 0.13 & 0.10 & 0.45 & 0.19 \\
Skewness & 0.08 & 0.86 & -0.28 & 0.13 & 0.27 \\
Kurtosis & 1.71 & 2.13 & 1.80 & 1.82 & 1.73 \\
Jarque-Bera & 8.50 & 18.72 & 8.87 & 7.35 & 9.41 \\
Probability & 0.01 & 0.00 & 0.01 & 0.03 & 0.01 \\
\hline
\end{tabular}

A study of the descriptive statistics shows approximate normality in the data distribution of each variable in terms of skewness and kurtosis. The coefficient of skewness of each 
variable is low and is positively skewed except for exchange rate. The figure for kurtosis in each variable is below its benchmark of 3 for a normal distribution, confirming near normality. The mean-to-median ratio of each variable is close to 1 . The range of variation between maximum and minimum is reasonable. The standard deviation is also quite low compared to the mean, showing a small coefficient of variation. Although the above descriptive statistics show the normality of each variable, the Jarque-Bera test indicates non-normality of the variables. However, the problem does not seem serious.

Table 2. Descriptive Statistics Test: Bangladesh (Return).

\begin{tabular}{llllll}
\hline & SPI & DR & ER & MS & CPI \\
\hline Mean & 0.02 & 0.00 & 0.00 & 0.01 & 0.01 \\
Median & 0.02 & 0.00 & 0.00 & 0.01 & 0.00 \\
Maximum & 0.26 & 0.00 & 0.06 & 0.06 & 0.04 \\
Minimum & -0.27 & -0.18 & -0.03 & -0.02 & -0.01 \\
Std. Dev. & 0.07 & 0.02 & 0.01 & 0.02 & 0.01 \\
Skewness & 0.14 & -7.60 & 2.55 & 0.72 & 1.01 \\
Kurtosis & 5.89 & 59.18 & 15.35 & 3.42 & 5.77 \\
Jarque-Bera & 41.71 & 16792.67 & 885.53 & 11.25 & 58.22 \\
Probability & 0 & 0.00 & 0.00 & 0.00 & 0 \\
\hline
\end{tabular}

The study of the descriptive statistics for return (Table 2) does not show normality in the data distribution of the variables in terms of skewness and kurtosis. Apart from the coefficients for stock price \& Money Supply, it is relatively high for others. The figure for kurtosis in each variable is above its benchmark of 3 for a normal distribution, confirming non-normality. Although the mean-to-median ratio of each variable is close to 1 and the range of variation between maximum and minimum is quite reasonable, the standard deviation is quite high compared to the mean, showing large coefficient of variation. In addition, the Jarque-Bera test indicates non-normality of the variables, indicating serious problem.

\section{Test for Stationarity}

The next set of tables summarizes the ADF test results for Bangladesh. The first panel of the tables present the ADF, PP and KPSS test statistics of the variables under study considering for with trend but no constant category. The $2^{\text {nd }}$ panel represents the critical values at 1,5 and 10 percent level for the test statistics. The optimal lag length the in the augmented Dickey-Fuller test, has been determined with the Schwarz criterion being the default. Schwarz's criterion has in this case chosen maximum 12 lags to perform the ADF test.

Table 3. Unit Root \& Stationarity Tests: Bangladesh.

\begin{tabular}{|c|c|c|c|c|c|c|c|}
\hline \multirow{2}{*}{ Variables } & \multicolumn{3}{|c|}{ Null Hypothesis: Variable is Non-Stationary } & \multirow{2}{*}{\multicolumn{2}{|c|}{$\begin{array}{l}\text { Null Hypothesis: Variable is Non- } \\
\text { Stationary } \\
\text { Phillips Peron (PP) Test Statistic }\end{array}$}} & \multirow{2}{*}{\multicolumn{2}{|c|}{$\begin{array}{l}\text { Null Hypothesis: Variable is Non-Stationary } \\
\begin{array}{l}\text { Kwiatkowski-Phillips-Schmidt-Shin (KPSS) } \\
\text { Test Statictic }\end{array}\end{array}$}} \\
\hline & \multirow{2}{*}{$\begin{array}{l}\begin{array}{l}\text { Augmented } \\
\text { statistic }\end{array} \\
\text { Level }\end{array}$} & \multirow{2}{*}{$\begin{array}{r}\text { Dickey-Fuller (ADF) } \\
\text { 1st Difference }\end{array}$} & \multirow[t]{2}{*}{ Test } & & & & \\
\hline & & & & Level & 1st Difference & Level & 1st Difference \\
\hline LnSPI & -0.10 & $-9.71 * * *$ & & -0.13 & $-9.67 * * *$ & 1.26 & $0.07 * * *$ \\
\hline Ln IR & -1.68 & $-10.96 * * *$ & & -1.68 & $-10.96 * * *$ & 1.06 & 1.06 \\
\hline LnER & -1.66 & $-11.54 * * *$ & & -1.78 & $-11.74 * * *$ & 1.24 & 0.53 \\
\hline LnMS & 2.35 & -2.22 & & 3.48 & $-16.63 * * *$ & 1.31 & $0.53^{* * *}$ \\
\hline LnINF & 0.72 & $-7.54 * * *$ & & 1.61 & $-7.09 * * *$ & 1.30 & $0.07^{* * *}$ \\
\hline \multicolumn{8}{|c|}{ Critical Values } \\
\hline $1 \%$ Level & -3.49 & & & -3.49 & & 0.74 & \\
\hline $5 \%$ Level & -2.89 & & & -2.89 & & 0.46 & \\
\hline $\begin{array}{l}10 \% \\
\text { Level }\end{array}$ & -2.58 & & & -2.58 & & 0.35 & \\
\hline
\end{tabular}

*** indicates stationarity at the first differencing

The calculated ADF and PP statistics cannot reject the null hypothesis of unit root at either the 1 percent, 5 percent or 1 percent significance levels when compared with the respective critical values as it is clear from the result that the test statistic is not more negative than the critical value. The calculated KPSS statistics also clearly reject the null hypothesis of no unit root at 1 percent, 5 percent or 10 percent significance levels when compared with the corresponding critical values. In other words, the ADF, PP and KPSS tests decisively confirm the nonstationarity of each variable. The above Table shows that LnSPI, LnDR and LnER and LnMS possess I(1) behaviour. To be precise, the stationarity of all variables except money supply is restored on first differencing, showing the same order of integration. On the other hand, stationarity for the variable MS restores at the 2nd differencing.

Cointegration Results and Long-run Equilibrium Relationship

Next the cointegration procedure developed by Johansen and Johansen \& Juselius is employed to test the long run equilibrium relationship between the stock price index and components of monetary policy.

The unit root test performed the section confirms that variables are all non-stationary in their levels form, which is the first step in cointegration analysis [44]. Johansen method uses likelihood ratio test to determine the number of cointegrating relationships, which may exist between the variables. If the hypothesis of no cointegration is rejected, then a stable long run relationship between stock index and related variable does exist. In Eviews we can perform the 
cointegration test and the subsequent estimation, under 5 assumptions. In this case, the cointegration test and the subsequent estimation is determined under the assumption of intercept with no trend in the potentially cointegrating relationship and/or the VAR. However, at firs by examining the sensitivity of the result to the type of specification has been used to determine the appropriate lag length for the test. The values of $\mathrm{AIC}^{2}$ and $\mathrm{SBIC}^{3}$ can be used to determine the optimal lag length. In this case AIC selects a VECM with 2 lags and SBIC a VECM with 0 lags.

Table 4. Trace Test: Bangladesh.

\begin{tabular}{llll}
\hline Null Hypothesis & Trace statistic & $\mathbf{5 \%}$ Critical value & Probability \\
\hline $\mathrm{r}=0$ & 40.75 & 69.81 & 0.94 \\
$\mathrm{r} \leq 1$ & 23.47 & 47.86 & 0.95 \\
$\mathrm{r} \leq 2$ & 11.49 & 29.80 & 0.95 \\
$\mathrm{r} \leq 3$ & 5.23 & 15.49 & 0.78 \\
$\mathrm{r} \leq 4$ & 0.00 & 3.84 & 0.99 \\
\hline
\end{tabular}

*denotes rejection of the hypothesis at the 0.05 level

Trace test indicates no cointegrating equations at the 0.05 level

Table 5. Maximum Eigen Value: Bangladesh.

\begin{tabular}{llll}
\hline Null Hypothesis & Max-Eigen statistic & 5\% Critical value & Probability \\
\hline $\mathrm{r}=0$ & 17.27 & 33.88 & 0.91 \\
$\mathrm{r} \leq 1$ & 11.98 & 27.58 & 0.93 \\
$\mathrm{r} \leq 2$ & 6.27 & 21.13 & 0.98 \\
$\mathrm{r} \leq 3$ & 5.23 & 14.26 & 0.71 \\
$\mathrm{r} \leq 4$ & 0.00 & 3.84 & 0.10 \\
\hline
\end{tabular}

*denotes rejection of the hypothesis at the 0.05 level

Max-eigenvalue test indicates no cointegrating equation(s) at the 5\% level

Table 6. Normalized Cointegrating Coefficients: Bangladesh.

\begin{tabular}{llll}
\hline Variables & Coefficient & Std. Error & t-statistic \\
\hline LSPI & 1.00 & - & - \\
LDR & 2.78 & 1.75 & 1.59 \\
LER & -0.37 & 2.68 & -0.14 \\
LMS & -5.07 & 1.06 & -4.78 \\
LCPI & -2.53 & 0.33 & -8.43 \\
Constant & 1552.31 & - & - \\
\hline
\end{tabular}

Critical value at $5 \%$ level of significance with 1 degree of freedom for the chi-square distribution: 3.841

*denotes rejection of the hypothesis at the 0.05 level

The results of Johansen Cointegration tests have been shown in a set of 3 tables. The first table shows the results for the $\lambda$ trace along with their test statics and probabilities. On the other hand the $2^{\text {nd }}$ table shows the $\lambda \max$ and their test statics and probabilities. Finally the last table in each set shows the estimation for normalized cointegration coefficient

Table 4 (Trace Test) provides the test statistics for cointegration vectors and critical values at 5 percent significance level. The result shown in the table is obtained by considering two lags and without any trend term. The test result clearly indicates that there is no relationship between LSPI. LDR, LER. LMS and LCPI as in each case the test statistic is lower than the critical value. Furthermore, Table 5 (Maximum Eigen Value ${ }^{4}$ Test) and Table 6 (Normalized Cointegrating Coefficients) also confirms the absence of a long-run equilibrium relationship between the variables.

\section{Short-run Dynamic Adjustment using VECM}

As mentioned earlier, the Vector Error Correction Model (VECM) allows us to make inferences on the long-run impacts of the variables in levels to those in differences [43]. The variables' responses to themselves are significant and negative which indicates positive autocorrelation. Generally, there are eight options for running a VEC model. However, in this study the VEC model has been run with no trend but with an intercept included. On the other hand, the optimal lag-interval has been determined by the values of AIC, estimated earlier by the sensitivity test which was performed in the Johansen Cointegration test under the category of summary of all assumptions. Hence, in this case AIC selected a VECM with 2 lags.

Table 7. Vector Error Correction Estimates: Bangladesh.

\begin{tabular}{llll}
\hline Variables & Coefficient & Std. Error & t-statistic \\
\hline Error correction term $(\rho)$ & 0.00 & 0.00 & -0.01 \\
D(SPI(-1)) & 0.07 & 0.10 & 0.74 \\
D(SPI(-2)) & -0.04 & 0.10 & -0.43 \\
D(DR(-1)) & -0.22 & 0.29 & -0.75 \\
D(DR(-2)) & -0.51 & 0.29 & -1.76 \\
D(ER(-1)) & 0.01 & 0.53 & 0.02 \\
D(ER(-2)) & -1.51 & 0.54 & -2.78 \\
D(MSY(-1)) & 0.81 & 0.7 & 1.15 \\
D(MSY(-2)) & 0.18 & 0.45 & 0.40 \\
D(CPI(-1)) & -0.11 & 0.8 & -0.14 \\
D(CPI(-2)) & -0.76 & 0.78 & -0.97 \\
Constant & 0.02 & 0.01 & 2.77 \\
R-squared & 0.20 & & \\
Adjusted R-squared & & 0.12 & \\
Residual Sum of Squares & 0.47 & & \\
F-statistic & 2.37 & & \\
\hline
\end{tabular}

Critical value at $5 \%$ level of significance with 1 degree of freedom for the chi-square distribution: 3.841

*denotes rejection of the hypothesis at the 0.05 level

From Table 7 it can be seen that, the estimated coefficient $(\lambda)$ of the error correction term $\rho$ is negative which is expected but it is not statistically significant in terms of its associated t-value. It confirms that there is no significant long-run equilibrium relationship exists among the variables or more preciously no long term causal flow runs from changes in interest rates, exchange rate, money supply or inflation to the stock market of Bangladesh. Moreover, the value of R-Square 0.20 or Adjusted R0Squared 0.12 also shows low explanatory power of the model. The F statistics at 2.37 shows only a modest result.

The coefficients of the subsequent lagged terms of changes in the discount rate reveal a short-term net negative but very small feedback effect from interest rate to stock market, as their sum is negative. This finding seems counter-intuitive. However, the associated T-values of the coefficients of the lagged variables are insignificant which indicates a very restrained influence of the exchange rate on stock market return. Similarly, the sum of the co-efficient of the lagged changes in the exchange rate reveals a short term net negative feedback from exchange rate to stock market which lowers the adjusted rate of returns for foreign investors. However, the associated T-values of the coefficients of the 
lagged variables are insignificant. The same trend goes with the variables Money Supply and Inflation. Even though both of them have a negative effect bit it is insignificant.

\section{Vector-Autoregressive Estimates}

In this the estimation of VAR and its interpretation has been discussed. It is clear from the earlier estimations that the relationship between the determinants of monetary policy and Stock Market is not that significant for Bangladesh. Moreover as per the trace statistics, no cointegration prevails in the system. Whereas according to the Monte Carlo Experiments reported in Cheung and Lai [54] suggest "that the trace test shows more robustness to both skewness and excess kurtosis in the residuals than the maximum eigen value cointegration prevails in the system" [36]. In consequence, we cannot reject the null hypothesis of no cointegration. As a result VAR is estimated by following the equation which is the main model for this article. A VAR is actually estimated in order to examine whether there are lead-lag relationships for the returns to the considering variables. The first step in determining optimal lag length and this can be achieved in a variety of ways. Here in this paper, lag-length has been determined by using the multivariate information criterion. EViews presents the values of various information criteria and other methods for determining the lag order. In this case, the Schwartz and Hannan--Quinn criteria both select a zero order as optimal, while Akaike's criterion chooses a $\operatorname{VAR}(3)$.

Table 8. Vector Autoregressive Estimates: Bangladesh.

\begin{tabular}{llll}
\hline Variables & Coefficient & Std. Error & t-statistic \\
\hline D(SPI(-1)) & 0.03 & 0.11 & .31 \\
D(SPI(-2)) & -0.03 & 0.10 & -.31 \\
D(SPI(-3)) & 0.11 & 0.10 & 1.11 \\
D(DR(-1)) & -0.28 & 0.30 & -0.93 \\
D(DR(-2)) & -0.48 & 0.29 & -1.65 \\
D(DR(-3)) & 0.20 & 0.30 & 0.68 \\
D(ER(-1)) & -0.07 & 0.54 & -0.12 \\
D(ER(-2)) & -1.52 & 0.55 & -2.76 \\
D(ER(-3)) & -0.91 & 0.57 & -1.60 \\
D(MSY(-1)) & 1.40 & 0.50 & 2.09 \\
D(MSY(-2)) & -0.47 & 0.51 & -0.92 \\
D(MSY(-3)) & -0.25 & 0.48 & -0.51 \\
D(CPI(-1)) & 0.94 & 0.81 & 0.12 \\
D(CPI(-2)) & -0.42 & 0.88 & 0.48 \\
D(CPI(-3)) & 0.47 & 0.87 & 0.54 \\
Constant & 0.02 & 0.02 & 1.06 \\
R-squared & 0.24 & & \\
Adjusted R-squared & 0.12 & & \\
Residual Sum of Squares & 0.44 & & \\
F-statistic & 2.01 & & \\
\hline
\end{tabular}

Critical value at $5 \%$ level of significance with 1 degree of freedom for the chi-square distribution: 3.841

*denotes rejection of the hypothesis at the 0.05 level

Table 8 shows not a very significant relationship among the variables based on the evidence of $F$ statistic 2.01. The associated t-values of the coefficient of the explanatory variables are also insignificant. This is also reflected in the numerical value of R-Square and Adjusted R-Squared which are 0.24 and 0.12 respectively. More preciously we can say that, the relationship between changes in stock market return and changes in the interest, exchange rates, changes in the money supply and changes in consumer production index is not very significant for Bangladeshi Market.

\section{Findings}

The main purpose of this article was to analyze the relationships dynamics between stock price index and monetary policy instruments. The key monetary policy instruments have been represented by discount rate, exchange rate, money supply and consumer price index as a representation of inflation. In this article, I have used several multivariate models to analyze the relevance such relationship between monetary policy and stock market in Bangladesh. However, unfortunately and surprisingly all the models nearly provided the same result of poor connection between stock market and monetary policy or less effectiveness of monetary policy in the a stock market The first multivariate model Johansen Cointegration found no cointegration which considers the relationship between stock market index with discount rate, exchange rate, money supply and consumer price index or inflation in the context of Bangladesh. Since there is no cointegration, it clearly indicates the non-existence of long run relationship between stock market and these fundamental monetary policy instruments. The second multivariate model that has been estimated to measure the effectiveness of monetary policy factors on stock market is the Vector Error Correction Mode. VECM generally provides the estimates short-run adjustment for the long run relationship between the stock market and monetary policy instruments. For Bangladesh, VECM found no significant long run relationship between stock price index and discount rate, exchange rate, money supply and consumer price index because of its insignificant error term. In addition to the long run relationship, there exists no strong argument in favour of the short term adjustment. It clearly indicates that, for economy of Bangladesh, VECM found no such type of adjustments, which in the absence of long run relationship, could make the stock market return converged to the long run equilibrium. This type of results indicates the high volatility of Dhaka stock exchange. In 2004, a study was conducted on the volatility of the DSE stock return by Imam and Amin [55], which also confirms that volatility of DSE return series increases over time. After that, comes the Vector Autoregressive multivariate model which has been considered as the main model for this article. Apparently in this study VAR almost provides the similar results as VECM. Even though few earlier studies claim the existence of significant relationship between stock market and monetary policy mechanism, the VAR model used here, reveals a not so very strong relationship between the stock market index and the other variables-discount rate, exchange rate, money supply and consumer price index. The poor connection has been even conformed by the very low $\mathrm{R}^{2}$ the exchange rate to stock market with insignificant associated T-values of the coefficients and insignificant t-values of the coefficients of 
the explanatory variables. Ultimately even from VAR we get the similar results of no effectiveness of monetary policy on Dhaka Stock Market. It indicates that Dhaka Stock exchange and the monetary policy framework of Bangladesh are independent of each other.

\section{Conclusion}

This article examined the connection between stock market and monetary policy framework for the economies of Bangladesh. Through this article I have attempted to investigate whether the actions of monetary policy regulators can explain stock market return in the long run by conducting a co-integration test and in the short run by the dynamics of Vector error Correction model or Vector Autoregressive model. However after conducting the empirical studies, it is found that there is no significant relationship between monetary policy instruments and stock market for in Bangladesh. The shallow and small size market of the country can be one of the reasons behind this. Nevertheless for an efficient stock market, it is expected that policy announcements should have a significant impact on the stock market. Generally, in an efficient market, the prices react instantly to new information. According to market efficiency theory, a market riding on stale information is informationally inefficient. In case of monetary policy framework, when a market anticipates an announcement to be forthcoming, it definitely should react to the unexpected component in the monetary policy shock.

In addition, the existence of such a relationship has important implications for both stock market participants and central bankers. For instance, with respect to the former this issue relates to the broader topic of stock price determination and portfolio formation, while the latter may be interested in knowing, whether monetary policy actions are transmitted through financial market. Theoretically the implications of monetary policy framework on stock price are intense, as we all know that central bank can affect stock market profoundly by altering the central bank discount rate. Many earlier researches conducted across a variety of countries have already proved the existence of such sensitivity and also proved that how beneficial that can become for the countries. In order to get the benefits many countries have already adopted a new policy framework that can which can affect the stock market positively. For example, explicit inflation targeting practised by UK, Sweden, and Canada or implicit targeting, where no formal targets are in place by U.S.

Moreover for developing or emerging countries like Bangladesh the importance of sound development of the market cannot be undermined. In order to make the market less volatile, stock markets in the country should have more trained professionals who can monitor the monetary policy mechanism. In addition, more people from both regulatory body and stock market should have involved in doing research on the sensitivity of stock market with respect to monetary policy. The regulatory body should make decisions regarding monetary policy in a predictable way, with providing adequate explanation for the investors. They should make information relevant for securities available to the stock market participants and also make sure the transparency and accountability of audit report. Furthermore, monetary authorities should exercise restraint in the use of policy instruments indiscriminately, because it is clearly evidenced that the use of monetary policy instruments affects the performance of the stock market to a very large extent. Lastly, another policy implication for Central Bank can be to maintain inflation at a reasonably low level so that it will not erode the real value of stock gains. Given this information, now it is the responsibility of the monetary authority to calibrate the appropriate policy response to potential stock price arrangements.

\section{References}

[1] Mohammad,S.d.,Hussain, A., \& Jalil, M. A.(2009). Impact of Macroeconomics Variables on Stock Prices: Emperical Evidance in Case of Kse (Karachi Stock Exchange). European Journal of Scientific Research 38(1), 97-102.

[2] Poole, W., Rasche, R. H., \& Thornton, D. L. (2002) "Market Anticipations of Monetary Policy Actions," Federal Reserve Bank of St. Louis Review, 84(4), 65-94.

[3] Cook, T., and Hahn, T. (1989). "The Effect of Changes in the Federal Funds Rate Target on Market Interest Rates in the 1970s." Journal of Monetary Economics, 24(9), pp. 331-51.

[4] Kuttner, K. N. (2001) "Monetary Policy Surprises and Interest Rates: Evidence from the Fed Funds Futures Market," Journal of Monetary Economics, 47(3), 523-44.

[5] Bredin, D., Hyde, S., Nitzsche, D., and Reilly, G. O. (2007), 'U.K. stock returns and the impact of domestic monetary policy shocks', Journal of Business, Finance and Accounting, $34,872-888$.

[6] Gregoriou, A., Kontonikas, A., MacDonald, R., and Montagnoli, A. (2009), 'Monetary policy shocks and stock returns: Evidence from the British market', Financial Markets and Portfolio Management, 23, 401-410.

[7] Ioannidis, C., \& Kontonikas, A. (2006). Monetary Policy and Stock Market: Some International Evidences, 1-25.

[8] Waud, R., (1970), "Public Interpretation of Federal Reserve Discount Rate Changes: Evidence on the "Announcement Effect", Econometrica, 38, 231-250.

[9] Bernanke, B. S., and Gertler, M. (1995), "Inside the Black Box: The Credit Channel of Monetary Policy Transmission," Journal of Economic Perspectives, 9 (4); 22-48.

[10] Mbutor, M. O. (2007), "The Lending Channel of Monetary Policy Transmission in Nigeria; Vector Autoregressive (VAR) Verification," Central Bank of Nigeria; Economic and Financial Review, 45.

[11] Uchendu (1996), "The Transmission of Monetary Policy in Nigeria". Central Bank of Nigeria: Economic and Financial Review, 34(2), $606-625$.

[12] Kim, K (2003) "Dollar Exchange Rate and Stock Price: Evidence from Multivariate Cointegration and Error Correction Model." Review of Financial Economics, 12, 301313. 
[13] Mukherjee, Tarun K. and Naka,.A(1995), "Dynamic Relations Between Macroeconomic Variables and the Japanese Stock Market: An Application of Vector Error Correction Model," The Journal of Financial Research, 18 (2), 223-235.

[14] Ibrahim, M. H. (2003), "Macroeconomic Variables and Stock Prices in Malaysia: An Empirical Analysis," Asian Economic Journal, 13 (2), 219 - 230.

[15] Tsoukalas, D.(2003), "Macroeconomic Factors and Stock Prices in the Emerging Cypriot Equity Market", Managerial Finance 29(4), 89-91.

[16] Thorbecke, W. (1997). "On Stock Market Returns and Monetary Policy". Journal of Finance, 52, 635-654.

[17] Boschen, J.F. and Mills, L.O. (1995). "The Relation between Money Market and Narrative Indicators of Monetary Policy," Economic Inquiry 23, pp. 24-45.

[18] Patelis, A., (1997). "Stock Return Predictability and the Role of Monetary Policy”. Journal of Finance, 52, 1951-1972.

[19] Cassola, N., \& Morana, C. (2006). Monetary Policy and The Stock Market in The Euro Area.Journal of Policy Modeling 26, 387-399.

[20] Jensen, G. R., and Johnson, R. R. (1995). "Discount Rate Changes and Security Returns in the U.S., 1962-1991." Journal of Banking and Finance, 19, 79-95.

[21] Jensen, G. R., Mercer, J. M., and Johnson, R. R. (1996). "Business Conditions, Monetary Policy, and Expected Security Returns", Journal of Financial Economics 40, 213237.

[22] Fama, E. and French, K. (1989), "Business Conditions and Expected Returns on Stocks and Bonds", Journal of Financial Economics, 25, 23-49.

[23] Omotor,D. G (2010). "Relationship between Inflation and Stock Market Returns: Evidence from Nigeria". Journal of Applied Statistics, 1(1), 1-15.

[24] Carlson, M.(2007)."A Brief History of the 1987 Stock Market Crash with a Discussion of the Federal Reserve Response," Finance and Economics Discussion Series 2007-13, Washington: Board of Governors of the Federal Reserve System.

[25] Nelson, C. R. (1976) "Inflation and Rates of Return on Common Stocks," Journal of Finance, 31(2), 471-483.

[26] Fama, E. F. and Schwert, G. W. (1977). "Asset Returns and Inflation”, Journal of Financial Economics, 5, 115-146.

[27] Ely, D. P., \& Robinson, K. J. (1997). “Are stocks a hedge against inflation? International evidence using a long-run approach", Journal of International Money and Finance, 16, 141-167.

[28] Osuagwu, E. S. (2009) "The Effect of Monetary Policy on Stock Market Performance in Nigeria", Nigerian Journal of Securities and Finance, 14, (2).

[29] Fama, E. F. (1981), "Stock Returns, Real Activity, Inflation and Money," American Economic Review, 71, 545-565.

[30] Benderly, J., and Burton, Z. (1985), "Inflation, Real Balances, Output and Real Stock Returns," American Economic Review, 1120-1123.
[31] Geske, R, \& Roll, R (1983), "The Fiscal and Monetary Linkage between Stock Returns and Inflation," Journal of Finance, 38, $1-33$.

[32] Kaul, G. (1987), "Stock Returns and Inflation: The Role of the Monetary Sector," Journal of Financial Economics, 18, 253 276.

[33] Zhao, X (1999), "Stock prices, inflation and output: Evidence from China," Applied Economics Letters, 6 (8), 510-51.

[34] Udegbunam, Ralph \& P. O. Eriki (2001), "Inflation and Stock Price Behavior: Evidence from Nigerian Stock Market, Journal of Financial Management \& Analysis, 20(14), 1-10.

[35] Ahmed, M. K., Akhtaruzzaman, M., and Barua, S. (2007). "Effects of Monetary Policy on Price Formation of Financial Assets:A Test for Bangladesh", Working Paper Series No: WP 0703, Policy Analysis Unit, Bangladesh Bank, Dhaka.

[36] Banerjee, P. K., \& Adhikary, B. K. (2009). "Dynamic Effects of Changes in Interest Rates and Exchange Rates on the Stock Market Return in Bangladesh". Ritsumeikan Journal of Asia Pacific Studies, 119-133.

[37] Saidjada, K. M., Hossain, M. S. and Rahman, M. H. (2014). "Effects of monetary policy on capital markets in Bangladesh", Bangladesh Bank Monetary Policy Review, 8(1), 50-62.

[38] Rahman, M. L., \& Uddin, J. (2009). "Dynamic Relationship between Stock Prices and Exchange Rates: Evidence from Three South Asian Countries", International Business Research, 2(2), 167-174.

[39] Alam, M., \& Uddin, G.S.(2009). "Relationship between Interest and Stock Prices: Empirical Evidences from Developed and Developing Countries". International Journal of Business and Management, 4(3), 43-51.

[40] Quadir, M. M. (2012). "The Effect of Macroeconomic Variables on Stock Returns on Dhaka Stock Exchange", International Journal of Economics and Financial Issues, 2(4), 480-487.

[41] Shen, C. H., and Wang, L. R. (1997). "Daily Serial Correlation, Trading Volume, and Price Limit”, Pacific Basin Finance Journal, 6, 251-274.

[42] Neri,S.(2004).Monetary Policy and Stock Price Theory \& Evidence.ournal of Economic Literature 32,7-47.

[43] Ahmed. M. N. and Imam M. O., (2007),"Macroeconomic Factors and Bangladesh Stock Market", International Review of Business Research Paper, 3( 5), 21-35.

[44] Brooks, C.(2008). Modern Introductory Econometrics for Finance (2nd.ed.), (pp.298-365). New York: Cambridge University Press.

[45] Said, S.E. and Dickey, D.(1984). "Testing for Unit Roots in Autoregressive Moving-Average Models with Unknown Order," Biometrika, 71, 599-607.

[46] Phillips, P. C. B., and P. Perron (1988). "Testing for Unit Roots in Time Series Regression," Biometrika, 75, 335-346.

[47] Kwiatkowski, D., Phillips, P.C.B., Schmidt, P., and Shin, Y. (1992). "Testing the Null Hypothesis of Stationarity Against the Alternative of a Unit Root," Journal of Econometrics, 54, 159-178. 
[48] Engle, R. F. and C. W. J. Granger (1987), "Cointergration and Error Correction: Representation, Estimation and Testing", Econometrica, 55 (2), 251-276.

[49] Ahmed,S. (2008). "Aggregate Economic Variables and Stock Market in India", International Research Journal of Finance and Economics, 14, 145-148.

[50] Johansen, S., and K. Juselius (1990), "Maximum likelihood estimation and inference on cointegration - with applications to the demand for money", Oxford Bulletin of Economics and Statistics, 52, 169-210.

[51] Juselius,k. (2006). "The cointegrated VAR model: Methodology and Applications", New York: Oxford University Press, 14-16.
[52] Sims, C. A. (1980). "Macroeconomics and reality", Econometrica, 48, 1-48.

[53] Rahman, T., \& Moazzem K. G. (2011). "Capital market of Bangladesh: Volatility in the Dhaka Stock Exchange (DSE) and role of Regulators", International Journal of Business and Management, 6(7), 86-93.

[54] Cheung, Y. W. and Lai, K. S.(1993). "Finite-Sample Sizes of Johansen's Likelihood Ratio Tests for Cointegration," Oxford Bulletin of Economics and Statistics, 55, 313- 28.

[55] Imam, M. O., and Amin, A. S. M. M. (2004). "Volatility in the Stock Return: Evidence from Dhaka Stock Exchange", Journal of the Institute of Bankers Bangladesh, 51(1), 01-08. 